\title{
Upaya pencegahan penyakit diare dengan peningkatan pengetahuan metode enam langkah cuci tangan pada santri Pondok Pesantren Thawalib Sriwijaya Palembang
}

\author{
Tia Sabrina ${ }^{*}$, Tyas Hestiningsih $^{2}$, Rima Zanaria ${ }^{1}$ \\ ${ }^{1}$ Bagian Mikrobiologi Klinik, Fakultas Kedokteran Universitas Sriwijaya, Palembang, Indonesia \\ ${ }^{2}$ Program Studi Kedokteran Gigi, Fakultas Kedokteran, Universitas Sriwijaya, Palembang, Indonesia \\ E-mail: tiasabrina.ts@gmail.com
}

\begin{abstract}
Abstrak
Angka kejadian penyakit diare masih tinggi di Indonesia. Penyakit ini sebagian besar diderita anak-anak, khususnya anak usia sekolah. Salah satu langkah pencegahan yang mudah dan sederhana adalah dengan menerapkan metode cuci tangan yang benar. Tujuan dari penelitian ini adalah untuk meningkatkan pengetahuan santri Pondok Pesantren Thawalib Sriwijaya Palembang tentang metode enam langkah cuci tangan. Peserta kegiatan ini adalah 55 santri kelas 7 SMP sampai dengan kelas 12 SMA. Metode kegiatan ini terdiri dari ceramah, diskusi dan praktik langsung cara mencuci tangan yang benar. Evaluasi hasil kegiatan dilakukan dengan menggunakan kuesioner pre-test dan post test. Dilakukan analisis statistik menggunakan uji $\mathrm{T}$ berpasangan, didapatkan hasil $\mathrm{p}=0.000$ dengan perbedaan rerata pre-test dan post test sebesar -4.000 dan interval kepercayaan $95 \%$ yaitu -4.429 hingga (-3.571). Terdapat peningkatan pengetahuan peserta tentang cara pencegahan penyakit diare dengan menerapkan metode enam langkah cuci tangan yang benar.
\end{abstract}

Kata kunci: Diare, Enam Langkah Cuci Tangan, Santri

\begin{abstract}
The efforts to prevent diarrhea by increasing knowledge about the six-step method of washing hands for students at Islamic Boarding School Thawalib Sriwijaya Palembang. The incidence of diarrhea is still high in Indonesia. This disease mostly affects children, especially school-age children. One of the easy and simple preventive steps is apply proper handwashing. The purpose of this study is to increase the knowledge of students of the Islamic Boarding School Thawalib Sriwijaya Palembang about the six-step method of washing hands. The participants are 55 students from 7th-grade junior high school to 12th-grade high school. The method consist of lectures, discussions and direct practice of how to wash hands properly. Evaluation is carried out using a pre-test and post-test questionnaire. The result of the paired T-test obtained $p=0.000$ with a mean difference of pre-test and post test is $-4,000$ and $95 \%$ confidence intervals is $-4,429$ to - 3,571. There was an increase in participants' knowledge about how to prevent diarrheal diseases by applying the six-step method of washing hands properly.
\end{abstract}

Keywords: Diarrhea, Six Steps of Washing Hands, Santri 


\section{PENDAHULUAN}

Kemajuan suatu bangsa tidak dapat terlepas dari kualitas sumber daya manusia (SDM). Perwujudan sumber daya manusia yang berkualitas sangat bergantung pada tingkat kesehatan yang baik. Upaya peningkatan kualitas kesehatan dapat dinilai dari angka kejadian penyakit menular. Salah satu penyakit menular yang sering terjadi pada masyarakat adalah penyakit diare.

Berdasarkan Pusat Data dan Informasi kemenkes RI, penyakit diare masih merupakan masalah kesehatan masyarakat di negara berkembang seperti di Indonesia, karena morbiditas dan mortalitasnya yang masih tinggi. Survei morbiditas yang dilakukan oleh Subdit Diare, Departemen Kesehatan dari tahun 2000 s/d 2010 terlihat kecenderungan insidens naik. Pada tahun 2000 Incidence Rate (IR) penyakit Diare 301/ 1000 penduduk, tahun 2003 naik menjadi 374 /1000 penduduk, tahun 2006 naik menjadi 423 /1000 penduduk dan tahun 2010 menjadi 411/1000 penduduk. Kejadian Luar Biasa (KLB) diare juga masih sering terjadi, dengan Case Fatality Rate (CFR) yang masih tinggi. Pada tahun 2008 terjadi KLB di 69 Kecamatan dengan jumlah kasus 8133 orang, kematian 239 orang (CFR 2,94\%). Tahun 2009 terjadi KLB di 24 Kecamatan dengan jumlah kasus 5.756 orang, dengan kematian 100 orang (CFR 1,74\%), sedangkan tahun 2010 terjadi KLB diare di 33 kecamatan dengan jumlah penderita 4204 dengan kematian 73 orang (CFR 1,74\%). ${ }^{1}$

Salah satu pencegahan paling sederhana yang dapat dilakukan pada penularan penyakit diare adalah dengan cara mencuci tangan. Cuci tangan sering dianggap sepele oleh kebanyakan orang. Beberapa anak-anak usia sekolah kurang memperhatikan perlunya cuci tangan dalam kehidupan sehari-hari, terutama ketika di lingkungan sekolah. Mereka langsung makan makanan yang mereka beli di sekitar sekolah tanpa cuci tangan terlebih dahulu. Perilaku tersebut tentunya berpengaruh dan dapat memberikan kontribusi dalam terjadinya penyakit diare. ${ }^{2}$ Oleh karena itu, sosialisasi tentang pentingnya cuci tangan yang benar pada anak-anak usia sekolah sangat perlu dilakukan dalam upaya penurunan angka kejadian diare. 
Pondok Pesantren Thawalib Sriwijaya Palembang yang berlokasi di Jl. Talang Kemang Kecamatan Gandus Palembang merupakan salah satu pusat pendidikan berbasis agama Islam yang mengasuh santri-santri dari mulai pendidikan tingkat pertama sampai pendidikan tingat atas. Anak-anak yang dididik di Pondok Pesantren ini tinggal di dalam lingkungan asrama. Kondisi lingkungan asrama merupakan salah satu faktor yang dapat mempengaruhi kondisi kesehatan anak-anak yang berada di dalamnya.

Adapun masalah yang dapat diidentifikasi yaitu kurangnya pengetahuan anak-anak usia sekolah tentang penyakit diare dan cara pencegahannya melalui cuci tangan yang benar. Hal tersebut menyebabkan kurangnya kesadaran anak untuk menerapkan cuci tangan di lingkungan sekolah. Oleh karena itu, sosialisasi tentang pentingnya cuci tangan yang benar pada anak-anak usia sekolah sangat perlu dilakukan dalam upaya penurunan angka kejadian diare.

Tujuan pengabdian masyarakat ini adalah meningkatkan pengetahuan santri Pondok Pesantren (Ponpes) Thawalib Sriwijaya Palembang tentang metode enam langkah cuci tangan yang benar dalam upaya pencegahan penyakit diare. Penerapan metode enam langkah cuci tangan yang benar dalam mencegah diare pada santri merupakan suatu hal yang sederhana dan mudah yang bisa dilakukan oleh anak-anak usia sekolah.

\section{TINJAUAN PUSTAKA}

Diare merupakan suatu keadaan buang air besar cair dengan frekuensi tiga kali atau lebih dalam sehari. Keadaan ini dapat bersifat akut jika disebabkan karena infeksi, namun dapat juga terjadi kronis yang bukan karena infeksi. ${ }^{3}$

Diare dikategorikan menjadi akut atau kronis dan menular atau tidak menular berdasarkan durasi dan jenis gejala. Diare akut didefinisikan sebagai episode yang berlangsung kurang dari 2 minggu. Infeksi paling sering menyebabkan diare akut. Sebagian besar kasus adalah akibat dari infeksi virus, dan dapat sembuh sendiri. Diare kronis didefinisikan sebagai durasi yang berlangsung lebih dari 4 minggu dan cenderung tidak 
menular. Penyebab umum termasuk malabsorpsi, penyakit radang usus, dan efek samping obat. ${ }^{4}$

Berdasarkan data Organisasi Kesehatan Dunia (WHO) dan UNICEF, ada sekitar dua miliar kasus penyakit diare di seluruh dunia setiap tahun. Sebanyak 1,9 juta anak di bawah lima tahun meninggal karena diare setiap tahun, sebagian besar berasal dari negara berkembang. Ini berjumlah $18 \%$ dari semua kematian anak-anak di bawah usia lima tahun dan berarti lebih dari 5000 anak meninggal setiap hari akibat penyakit diare. Dari semua kematian anak akibat diare, 78\% terjadi di wilayah Afrika dan Asia Tenggara. ${ }^{5}$

Norovirus dikaitkan dengan sekitar seperlima dari semua kasus diare menular, dengan prevalensi yang sama pada anak-anak dan orang dewasa, dan diperkirakan menyebabkan lebih dari 200.000 kematian setiap tahun di negara-negara berkembang. ${ }^{6}$

Diare adalah hasil dari berkurangnya penyerapan air oleh usus atau peningkatan sekresi air. Sebagian besar kasus diare akut disebabkan oleh infeksi. Diare kronis umumnya dikategorikan menjadi tiga kelompok; berair, berlemak (malabsorpsi), atau menular. ${ }^{3}$

Pada diare yang disebabkan oleh bakteri dan virus, tinja berair adalah hasil dari cedera pada epitel usus. Sel epitel melapisi saluran usus dan memfasilitasi penyerapan air, elektrolit, dan zat terlarut lainnya. Etiologi infeksius menyebabkan kerusakan pada sel epitel yang menyebabkan peningkatan permeabilitas usus. Sel-sel epitel yang rusak tidak dapat menyerap air dari lumen usus yang menyebabkan kotoran longgar. ${ }^{3}$

Gejala penyakit diare digambarkan dengan peningkatan frekuensi tinja, peningkatan volume tinja, dan / atau penurunan konsistensi tinja. Tanda penyakit diare ditandai dengan peningkatan ekskresi air tinja hingga lebih dari 150 hingga $200 \mathrm{ml}$ setiap 24 jam. ${ }^{3}$

Pencegahan diare yang disebabkan oleh infeksi salah satunya adalah dengan mencuci tangan dengan benar untuk mencegah penyebaran infeksi. ${ }^{7}$ Cuci tangan merupakan metode paling efektif dalam pencegahan penyakit infeksi. Cuci tangan yang konsisten dapat mengurangi kejadian diare dan penyakti pernafasan. ${ }^{8}$ 
Cuci tangan pakai sabun (CTPS) dapat mengurangi diare sebanyak $31 \%$ dan menurunkan penyakit infeksi saluran nafas atas (ISPA) sebanyak $21 \%$. Riset global juga menunjukkan bahwa kebiasaaan CTPS tidak hanya mengurangi, tapi mencegah kejadian diare hingga $50 \%$ dan ISPA hingga $45 \% .^{9}$

\section{METODE}

Untuk memecahkan masalah yang telah diidentifikasi dan dirumuskan, maka model kegiatan pengabdian masyarakat ini menggunakan model pemberdayaan. Model ini mengumpulkan khalayak sasaran untuk dilakukan pembinaan terkait peningkatan pengetahuan dan kesadaran akan pentingnya sikap hidup bersih. Adapun metode kegiatan yang digunakan yaitu:

1. Ceramah bervariasi.

Metode yang paling efektif untuk menyampaikan materi kepada massa yang banyak adalah dengan cara ceramah. ${ }^{10}$ Metode ini dipilih untuk menyampaikan konsep-konsep yang penting untuk dimengerti dan dikuasai oleh peserta pelatihan. Penggunaan metode ini dengan pertimbangan bahwa metode ceramah yang dikombinasikan dengan membagikan materi kepada santri seperti instrumen dan lainnya serta tampilan presentasi dilengkapi dengan gambar-gambar, animasi dan display dapat memberikan materi yang relatif banyak secara padat, cepat dan mudah.

2. Diskusi

Metode ini dipilih untuk melengkapi metode ceramah. Diskusi dilakukan setelah penyampaian materi, dimana peserta diperbolehkan mengajukan pertanyaan yang terkait materi dipandu oleh moderator dan peserta lain serta narasumber dipersilahkan untuk menanggapi pertanyaan.

3. Praktek enam langkah cuci tangan

Metode ini sangat membantu peserta untuk memahami secara langsung metode enam langkah cuci tangan yang benar. 
Metode 6 langkah cuci tangan menurut WHO: ${ }^{11}$

1. Tuang cairan handrub pada telapak tangan kemudian usap dan gosok kedua telapak tangan secara lembut dengan arah memutar

2. Usap dan gosok juga kedua punggung tangan secara bergantian

3. Gosok sela-sela jari tangan hingga bersih

4. Bersihkan ujung jari secara bergantian dengan posisi saling mengunci

5. Gosok dan putar kedua ibu jari secara bergantian

6. Letakkan ujung jari ke telapak tangan kemudian gosok perlahan

\section{HASIL DAN PEMBAHASAN}

Kegiatan pengabdian masyarakat ini dilaksanakan dalam 1 hari, pada tanggal 14 November 2019, dari pukul 09.00 WIB s/d 12.00 WIB. Peserta santri sebanyak 55 orang santri, terdiri dari 44 santriwan dan 11 santriwati. Kegiatan dimulai dengan acara pembukaan dari pihak Pondok Pesantren Thawalib Sriwijaya Palembang dan dihadiri juga oleh para guru.

Setelah pembukaan, acara dilanjutkan dengan kegiatan penyuluhan. Sebelumnya, para santri diminta untuk mengisi lembar pretest yang sudah diberikan sebelumnya. Lembar pre-test yang sudah diisi, dikumpulkan lagi.

Kegiatan penyuluhan dimulai dengan memberikan materi dengan metode ceramah bervariasi. Pada sesi ini, penyuluh memberikan penjelasan tentang penyakit diare, penyebab diare, cara penularan dan cara pencegahan penyakit diare. Penyuluh memberikan informasi cara pencegahan penyakit diare yang paling mudah, murah dan sederhana adalah dengan metode enam langkah cuci tangan yang benar. Penyuluh menjelaskan tahapan cuci tangan yang benar dan cara mencuci tangan yang benar disertai leaflet, gambar dan video.

Sesi selanjutnya adalah sesi diskusi. Pada sesi ini, para santri ini diperbolehkan untuk mengajukan pertanyaan apabila masih terdapat penjelasan yang belum dipahami. Pada sesi 
ini terdapat dua pertanyaan dari santri, yaitu mengenai jenis sabun yang dipakai untuk mencuci tangan dan pengobatan diare.

Setelah diskusi selesai, selanjutnya dilakukan sesi praktik metode enam langkah cuci tangan. Penyuluh memberikan contoh metode enam langkah cuci tangan di depan kelas dan diikuti oleh para santri. Selain dari cara yang sudah didemonstrasikan di depan kelas, para santri dapat juga mengikuti cara cuci tangan yang benar dengan melihat panduan dari leaflet yang sudah diberikan pada awal kegiatan. Pada sesi ini, para santri mempraktikan metode enam langkah cuci tangan yang benar dengan menggunakan cairan pencuci tangan yang berbasis alkohol yang sudah diberikan pada masing-masing santri. Untuk lebih meningkatkan pemahaman tentang praktik cuci tangan ini, penyuluh mengulang sampai 3 kali tentang praktik cuci tangan yang benar.

Kegiatan penyuluhan ini ditutup dengan membagikan lembar post-test, untuk diisi kembali oleh para santri. Lembar post-test yang sudah diisi kembali dikumpulkan untuk dianalisis.

Program pengabdian pada yang telah dilaksanakan ini diharapkan dapat menambah pengetahuan siswa sebagai salah satu upaya menciptakan hidup bersih dan sehat. Hasil penyuluhan ini akan bermanfaat bagi sekolah (pondok pesantren), sehingga kegiatan belajar mengajar dapat berjalan baik dan efektif karena diikuti oleh peserta didik yang sehat dan mampu meningkatkan prestasi belajar.

Hasil kegiatan PPM secara garis besar mencakup beberapa komponen sebagai berikut:

1. Keberhasilan target jumlah peserta pelatihan

2. Ketercapaian tujuan pelatihan

3. Ketercapaian target materi yang telah direncanakan

4. Kemampuan peserta dalam penguasaan materi

Masalah yang menjadi fokus dalam pelatihan ini adalah bagaimana santri pondok pesantren dapat menerapkan pola hidup bersih dan sehat yang salah satu upayanya dengan 
mencuci tangan yang benar. Praktik mencuci tangan yang benar adalah upaya lanjutan dalam memaksimalkan proses pemahaman santri pada metode enam langkah cuci tangan yang benar.

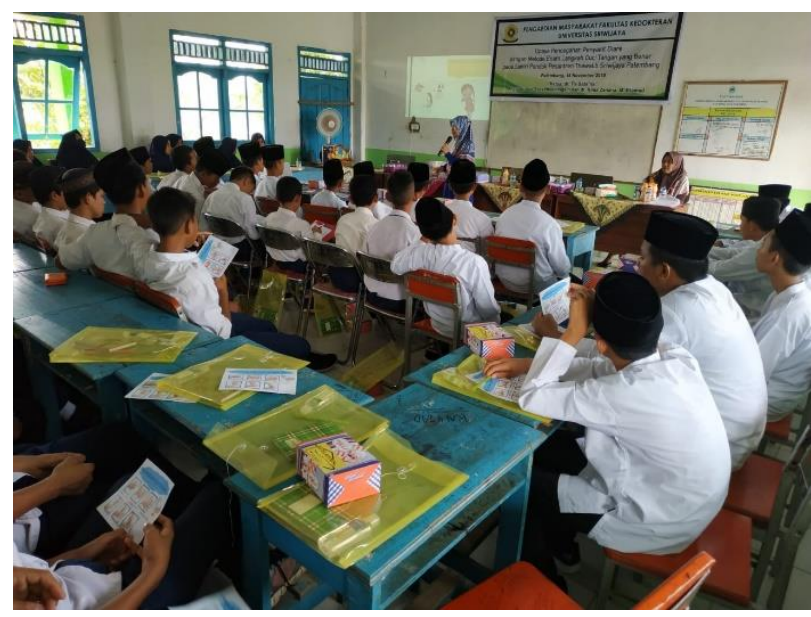

Gambar 1. Pemateri sedang menyampaikan materi

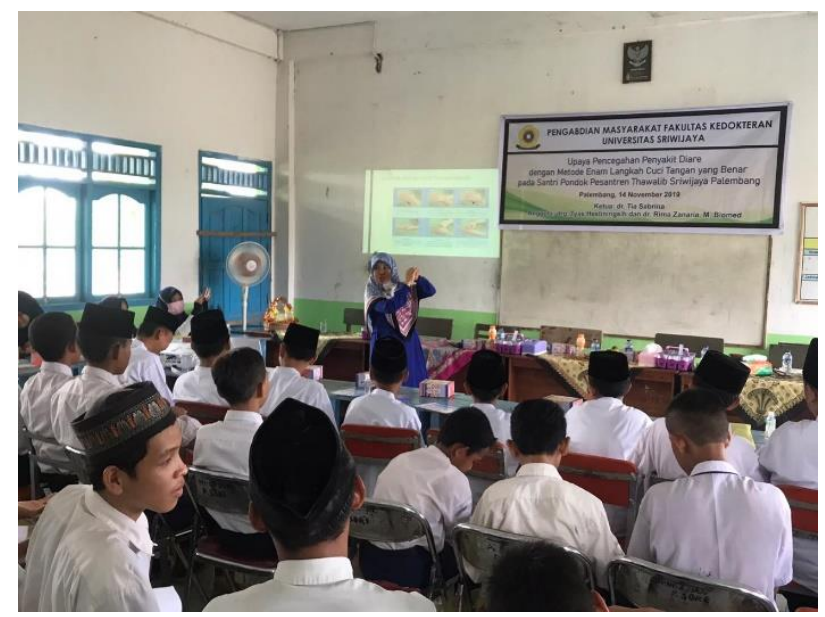

Gambar 2. Praktik cuci tangan

Dari hasil kegiatan secara keseluruhan, didapatkan respon peserta yang menghadiri penyuluhan dapat dikategorikan baik. Hal ini diketahui dari hasil pengamatan langsung pada saat kegiatan sedang berlangsung. Para peserta tidak sungkan dalam mengutarakan pertanyaan yang dirasa masih berkaitan dengan materi pelatihan.

Berdasarkan hasil kuesioner tentang upaya pencegahan penyakit diare dengan metode enam langkah cuci tangan yang benar diperoleh bahwa seluruh peserta kegiatan sudah memahami enam langkah mencuci tangan yang benar sebagai upaya pencegahan penyakit diare. Penerapan metode enam langkah cuci tangan yang benar merupakan salah satu langkah efektif yang murah dan sederhana yang dapat dilakukan oleh setiap individu untuk mencegah penyakit diare. Sebagian besar peserta telah mengetahui tentang penyakit diare, namun cara penularan dan pencegahan penyakit diare baru diketahui setelah kegiatan pemberian materi ini dilaksanakan. Pencegahan penyakit diare yang dilakukan dengan mencuci tangan yang benar ini dapat dilakukan peserta menggunakan cairan 
pencuci tangan yang berbasis alkohol. Cuci tangan dapat dilakukan dengan air mengalir serta sabun maupun cairan pencuci tangan berbasis alkohol.

Tabel 1. Uji T dua sampel berpasangan terhadap skor pre dan post-test

\begin{tabular}{lcccc}
\hline \multicolumn{1}{c}{$\begin{array}{c}\text { Skor } \\
\text { Pengetahuan }\end{array}$} & Rerata & $\begin{array}{c}\text { Perbedaan } \\
\text { Rerata }\end{array}$ & Interval Kepercayaan 95\% & Nilai Pa \\
\hline Pre-Test & 6.93 & -4.000 & $-4.429-(-3.571)$ & $0.000^{*}$ \\
Post-Test & 10.93 & & & \\
${ }^{*}: p<0.05$ & & & & \\
a: Paired T-Test & & & &
\end{tabular}

Analisis pada hasil pre dan post-test menunjukan bahwa kegiatan penyuluhan yang dilakukan efektif dalam mengingkatkan pengetahuan peserta terkait pencegahan penyakit diare. Hal ini terlihat dari adanya peningkatan skor rerata pengetahuan peserta pelatihan setelah dilakukan pelatihan. Rata-rata peserta pelatihan sudah mengetahui tentang penyakit diare dan cara pencegahan penyakit diare dengan metode enam langkah cuci tangan yang benar. Peserta juga telah memahami langkah-langkah cara mencuci tangan yang benar. Hal ini sesuai dengan pengamatan yang dilakukan oleh Juariah, anak-anak usia sekolah masih memiliki tingkat pengetahuan dan pemahaman yang rendah tentang kebersihan diri, terutama tentang metode cuci tangan yang benar. Peningkatan pengetahuan di antara anak usia sekolah dapat dilakukan dengan penyuluhan dan pelatihan cuci tangan yang benar. ${ }^{12}$

\section{SIMPULAN}

Kegiatan pengabdian masyarakat yang berjudul Upaya Pencegahan Penyakit Diare dengan Metode Enam Langkah Cuci Tangan yang Benar dapat terselenggara dengan baik dan berjalan lancar sesuai dengan rencana yang telah disusun. Para peserta kegiatan terlihat antuasis dalam memberikan pertanyaan pada saat diskusi. Terdapat peningkatan pengetahuan peserta yang terlihat dari hasil analisis data kuesioner, menunjukkan bahwa kegiatan ini berhasil memberikan manfaat kepada peserta. 


\section{Ucapan Terima Kasih}

Ucapan terima kasih ditujukan kepada teman-teman sejawat yang sudah membantu pada kegiatan ini serta Fakultas Kedokteran Unsri yang telah membiayai kegiatan ini. Dana kegiatan berasal dari DIPA Fakultas Kedokteran Universitas Sriwijaya No. SP DIPA042.01.2.400953/2019, tanggal 5 Desember 2018, sesuai dengan Surat Perjanjian Nomor: 109/013/UN9.1.4/PLP-PPM/PL/X/2019 Tanggal: 1 Oktober 2019.

\section{Referensi}

1. Pusat Data Dan Informasi - Kementerian Kesehatan Republik Indonesia. Diare [Internet]. 2011. Available From: https://Pusdatin.Kemkes.Go.Id/Article/View/13010200028/Diare.Html

2. Purwandari R, Ardiana A, Wantiyah. Hubungan antara perilaku mencuci tangan dengan insiden diare pada anak usia sekolah di Kabupaten Jember. J Keperawatan. 2015;4(2).

3. Nemeth V, Pfleghaar N. Diarrhea. In: Statpearls [Internet]. Statpearls Publishing; 2017.

4. Wenzl Hh. Diarrhea in chronic inflammatory bowel diseases. Gastroenterol Clin. 2012;41(3):651-75.

5. Farthing M, Salam Ma, Lindberg G, Dite P, Khalif I, Salazar-Lindo E, Et Al. Acute diarrhea in adults and children: A Global Perspective. J Clin Gastroenterol. 2013;47(1):12-20.

6. Lopman Ba, Steele D, Kirkwood Cd, Parashar Ud. The vast and varied global burden of norovirus: prospects for prevention and control. Plos Med. 2016;13(4):E1001999.

7. Null C, Stewart Cp, Pickering Aj, Dentz Hn, Arnold Bf, Arnold Cd, Et Al. Effects of water quality, sanitation, handwashing, and nutritional interventions on diarrhoea and child growth in rural Kenya: A cluster-randomised controlled trial. Lancet Glob Heal. 2018;6(3):E316--E329.

8. Luby Sp, Agboatwalla M, Bowen A, Kenah E, Sharker Y, Hoekstra Rm. Difficulties in maintaining improved handwashing behavior, Karachi, Pakistan. Am J Trop Med Hyg. 2009;81(1):140-5.

9. Fazriyati W. Kebiasaan CTPS di RS tekan infeksi nosokomial. 2013.

10. Notoatmojo. Promosi kesehatan. Jakarta: Rineka Cipta; 2007.

11. World Health Organization. WHO guidelines on hand hygiene in health care: a summary [Internet]. 2009. P. 15.

12. Juariah S, Yusrita E, Darmadi D, Irawan Mp, Kurniati I. Pengenalan, pemantauan dan penyuluhan pentingnya personal higiene di SMAN X Pekanbaru. J Pengabdi Masy Multidisiplin. 2018;2(2):168-73. 